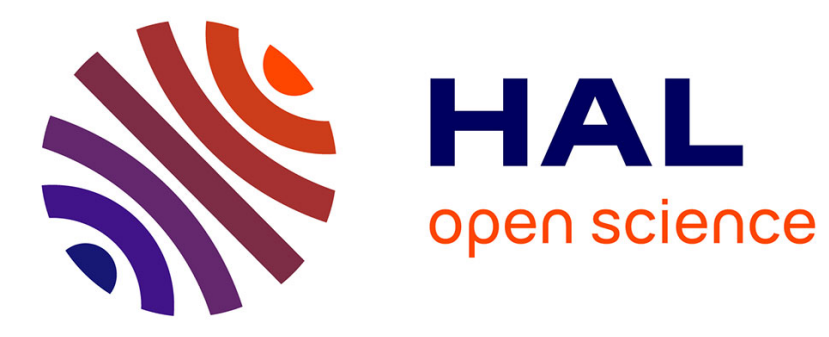

\title{
Electrochemical technologies coupled with biological treatments
}

Emmanuel Mousset, Clément Trellu, H. Olvera-Vargas, Yoan Pechaud, F. Fourcade, Mehmet A. Oturan

\section{- To cite this version:}

Emmanuel Mousset, Clément Trellu, H. Olvera-Vargas, Yoan Pechaud, F. Fourcade, et al.. Electrochemical technologies coupled with biological treatments. Current Opinion in Electrochemistry, 2021, 26, pp.100668. 10.1016/j.coelec.2020.100668 . hal-03130419

\author{
HAL Id: hal-03130419 \\ https://hal.science/hal-03130419
}

Submitted on 18 Feb 2021

HAL is a multi-disciplinary open access archive for the deposit and dissemination of scientific research documents, whether they are published or not. The documents may come from teaching and research institutions in France or abroad, or from public or private research centers.
L'archive ouverte pluridisciplinaire $\mathbf{H A L}$, est destinée au dépôt et à la diffusion de documents scientifiques de niveau recherche, publiés ou non, émanant des établissements d'enseignement et de recherche français ou étrangers, des laboratoires publics ou privés. 
1 Electrochemical technologies coupled with biological treatments

3 Emmanuel Mousset ${ }^{1, *}$, Clément Trellu $^{2}$, Hugo Olvera-Vargas ${ }^{3}$, Yoan Pechaud $^{2}$,

${ }^{1}$ Laboratoire Réactions et Génie des Procédés, Université de Lorraine, CNRS, LRGP, F54000 Nancy, France

${ }^{2}$ Université Gustave Eiffel, Laboratoire Géomatériaux et Environnement EA 4508, 77454 8 Marne-la-Vallée, Cedex 2, France

${ }^{3}$ Instituto de Energías Renovables, Universidad Nacional Autónoma de México (IER-

${ }^{4}$ Univ Rennes, Ecole Nationale Supérieure de Chimie de Rennes, CNRS, ISCR - UMR6226, 


\section{Abstract}

25 When possible, the bioprocesses should be implemented to treat wastewater for their cost-

26 effectiveness. However, many effluents are composed of biorecalcitrant organic pollutants, 27 especially in industrial wastewaters. Advanced physico-chemical treatments are therefore 28 needed to deal with these pollutions. Electrochemical processes could be cost-effective 29 solutions. However, the energy required to reach complete mineralization is often high. One 30 promising combination would be to combine electrochemical processes that can remove 31 xenobiotic compounds from effluent with biotechnologies that are able to mineralize the 32 biodegradable fraction. Therefore, this review presents the most recent articles dealing with 33 this combination, by mainly focusing on electrochemical advanced oxidation processes that 34 demonstrated to have high removal efficiency for organic biorecalcitrant compounds. 35 Additional and imperative information about the treatment strategy and the engineering aspects for the upscaling approach are also given.

37

38

\section{Keywords:}

40

41

Anodic oxidation; Bioreactor; Biorecalcitrant; Electro-Fenton; Hydroxyl radicals; Wastewater treatment 


\section{Highlights}

45 - A combination strategy between electrochemical and bio- processes is proposed

46 - Combinations between anodic oxidation and bioprocesses are reviewed

47

- Combinations between Fenton-based treatment and bioprocesses are discussed

48

- Combinations between electro-coagulation and bioprocesses are considered

49

- The engineering approach, scale up studies and future challenges are exposed

50

51 
Electrochemical processes are gaining interest in wastewater treatment area, due to their

54

55

56

57

58 ability to degrade and mineralize biorecalcitrant organic pollutants using electron as clean reagent [1-4]. In the meanwhile, they can remove the biorecalcitrant part of effluent which makes interesting their coupling with biological technologies [5]. This synergy would also reduce the high energy consumption required in an electrochemical process for complete mineralization.

This review intends to relate the most recent works on this combination in a context of wastewater treatment. The feasibility of combination, needed to address a treatment strategy, is firstly discussed. Then the main electrochemical processes such as electrochemical advanced oxidation processes (EAOPs) (i.e. anodic oxidation (AO), electro-Fenton (EF)) and electrocoagulation (EC) are presented successively. The coupling efficiency with biological technologies (e.g. aerobic, anaerobic, membrane bioreactors, microbial fuel cell) is examined in the meantime. The engineering approach and scale-up studies are finally showcased and the future challenges for industrial applications are highlighted.

\section{Combination feasibility and treatment strategy}

Standardized tests [6,7] can be implemented on the effluent to be treated and on the electrolyzed solutions to estimate the combination feasibility. In these assays, the estimation is based on the dissolved organic carbon (DOC) evolution [6] or the production of carbon dioxide [7] during 28 days of biological culture. Oxygen uptake rate can be also monitored [8]. Biodegradability is often estimated by the biochemical oxygen demand (BOD) after 5 days / chemical oxygen demand (COD) ratio $[9,10]$. Although this estimation is quicker, it has to be interpreted with some cautions. The ratio value may increase due to some biodegradable compounds in the solution but if the major part of the organic content is still recalcitrant, a significant mineralization cannot be reached [11]. Similarly, a low value does not necessarily mean an absence of biodegradability since an acclimation period can be needed for microorganisms to metabolize the organic content, particularly in the case of industrial effluents with very specific characteristics [12,13]. Ultimate BOD obtained after 21 days of incubation can help with the decision about the biodegradability. 
Due to the high response time with microorganisms - at least 5 days - physico-chemical tools were considered as the combination between total organic carbon (TOC) and COD. The average oxidation state (AOS) or COD/TOC ratio can give information on effluent oxidation and then its possible biodegradation [14].

Moreover, toxicity assays can be performed in addition to biodegradability estimation. Microtox is the most widely adopted and concerns acute toxicity [9]. Phytotoxic tests based on germination index can also be considered [15].

Pollutant concentration or molecular structure can influence the biodegradability. For instance, no inhibition of sodium benzoate biodegradation occurred with the addition of tetracycline concentration less than $5 \mathrm{mgL}^{-1}$ [7]. Biorecalcitrance of alachlor is due to the chlorine atom and to the amide group in its structure [11]. Furthermore, the formation of biodegradable intermediates depends on the operational conditions of the electrolysis $[11,14]$.

The combination strategy depends on the nature of the effluent and on the estimation of its biodegradability. An electrochemical pre-treatment should be prioritized in the presence of toxic and/or biorecalcitrant and/or inhibitory compounds for microbial activity. A biological pre-treatment can be considered when the biorecalcitrant part of the effluent does not hinder the microbial growth $[9,10]$ (Figure 1).

\section{Anodic oxidation coupled with biological treatments}

AO process is an EAOP based on the generation of strong oxidants like hydroxyl radical $(\mathrm{OH})$ from oxidation of water in the region of water discharge [2,16]. This radical is chemisorbed in the case of active anodes like carbon, Pt or dimensionally stable anode (DSA) (with low oxygen evolution overpotential) whereas it is slightly adsorbed (physisorption) and therefore more available for oxidation of organics in the case of non-active anodes having high oxygen evolution overpotential like boron-doped diamond anode (BDD), $\mathrm{PbO}_{2}, \mathrm{Ti}_{4} \mathrm{O}_{7}$ [17-19]. However, the efficiency of this process depends strongly on the concentration of organic compounds in the solution and mass transport conditions from the solution to the anode surface [20,21]. Other oxidant species can be also generated (persulfate, sulfate radicals, active chlorine, ozone) depending on ions present in the solution and operating conditions $[2,22,23]$.

Several studies have been performed on the combination of $\mathrm{AO}$ with a biological treatment in order to improve the cost-effectiveness of the process (Table 1) [6,24-30]. There are three 
114 main advantages from the use of $\mathrm{AO}$ as a pre-treatment: (i) $\mathrm{AO}$ is well known for its non-

115 selectivity towards organic compounds and can be applied to a large range of effluents (Table

116 1), (ii) AO is able to avoid the accumulation of toxic organic by-products because of the fast

117 transformation of organics into harmless by-products or even mineral compounds, (iii) higher

118 current efficiency is usually reported for the treatment of concentrated effluents (such as

119 industrial effluents with low biodegradability: landfill leachates, textile industry effluents, etc)

120 with low biodegradability and COD concentration higher than $100 \mathrm{mg}-\mathrm{O}_{2} \mathrm{~L}^{-1}$.

121 However, AO presents also some drawbacks for a combination with a biological process. Fast 122 mineralization kinetics but slower degradation kinetics are usually reported compared to other 123 EAOPs such as EF [31]. This phenomenon might affect the combination with a post124 biological treatment since initial compounds are more slowly degraded and a large amount of 125 biodegradable compounds is mineralized instead of being accumulated for subsequent cost126 effective removal by a biological treatment. The use of active anode would avoid the fast 127 mineralization and therefore may increase the amount of biodegradable intermediates, as 128 recently assessed [25]. It is also important to consider possible formation of toxic by-products 129 that might affect the biomass of the biological treatment, particularly inorganic species such as chlorate, perchlorate or ammonia [32-34]. Finally, it might be not suitable to use AO as a post-treatment following a biological treatment because of strong mass transport limitation and low faradaic efficiency due to the low concentration of organics. However, the use of

133 flow-through electrodes in which the effluent flow through porous conductive materials might 134 be able to address this issue because of the convection-enhanced mass transport of organic 135 compounds [21,35-38].

136 Another approach recently reported in the literature is the possibility to combine AO with a 137 biological treatment in a hybrid reactor instead of the implementation of a sequential 138 combined process. Particularly, the integration into a membrane bioreactor has been studied 139 in order to address fouling issues and to improve the removal of recalcitrant micropollutants 140 [39-42]. However, further development of such reactor configuration is required for (i) 141 improving electrode activity for removal of organic micropollutants, (ii) reducing mass 142 transport limitations, (iii) studying the influence of the electrical field on bacterial diversity 143 and activity, and (iv) assessing the influence of the large concentration of organic matter in 144 the mixed liquor on the efficiency of AO.

\section{Fenton-based electrochemical treatments coupled with biological processes}


The EF processs is based on the cathodic production of $\mathrm{H}_{2} \mathrm{O}_{2}$ at a suitable electrode material (generally carbon-based) through the 2-e $\mathrm{e}^{-}$reduction of $\mathrm{O}_{2} \cdot \mathrm{H}_{2} \mathrm{O}_{2}$ entails the generation of ${ }^{\circ} \mathrm{OH}$ via the Fenton's reaction in the presence of $\mathrm{Fe}^{2+}$ ions, which are externally added at a catalytic amount and electrochemically regenerated also at the cathode surface [2]. EF has been applied with success to treat several types of wastewaters contaminated with a variety of pollutants, becoming one of the most widely studied EAOPs [43]. Following the combination trends of AOPs with biological processes, EF has been an excellent option to handle recalcitrant pollutants resisting biological degradation such as most of pesticides, synthetic dyes, industrial chemicals, pharmaceuticals, etc. Therefore, different coupled strategies (either sequenced or integrated processes) have been proposed (Table 2) [15,44-58]. In the case of sequenced processes (pioneered by the groups of Oturan [59] and Fourcade [15]), the most common approach has been the use of $\mathrm{EF}$ as pre-treatment step to increase the biodegradability of refractory effluents during a short treatment time (to save electrical energy for cost effectiveness) $[59,60]$, whereas the remaining biodegradable organics are treated by conventional biological means. As a less popular option, EF has also been used as posttreatment following biological degradation to deplete the remaining bio-recalcitrant compounds. In such sequenced methods, conventional EF (catalyzed either by $\mathrm{Fe}^{2+}$ in solution (homogenous EF) or solid Fe catalysts (heterogeneous EF)) has been generally performed in undivided electrolytic cells with optimization of the main operating parameters affecting the efficiency (current density, electrode materials, catalyst concentration, etc.), while aerobic treatment with different microbial sources has been the preferred option. It is important to note that $\mathrm{pH}$ adjustment is generally required after/prior to EF, which is typically conducted at $\mathrm{pH} 3$ in the case of homogeneous EF [2].

Another kind of Bio-EF system, known as microbial-electro-Fenton (MEF), involves the incorporation of an EF half-cell in a microbial fuel cell (MFC) [61-63]. During MEF, the EF degradation of pollutants takes place in the cathode chamber equipped with a carbonaceous

173 cathode capable of producing $\mathrm{H}_{2} \mathrm{O}_{2}$ and containing a catalyst source $\left(\mathrm{Fe}^{2+}\right.$ in the solution or 174 Fe particles impregnated on the cathode). The anodic compartment contains anaerobic 175 electrogenic communities adhered to the anode surface that are able to produce electricity 176 through the oxidation of an organic substrate (i.e. acetate or wastewater). Wastewater 177 treatment can occur at both the biological and the EF chambers, generally with electricity 178 output, though low potentials have also been applied to enhance the performance. The main 179 advantage of MEF is the sustainable generation of electricity by the microorganisms. 
180 However, long stabilization and treatment times (several weeks) are required unlike

181 sequenced systems, with short EF treatment times (few hours), but prolonged biological incubations. Despite the great potential of bio-EF systems, further research is needed mainly in the treatment of real wastewaters and the development of larger-scale (bio)electrochemical reactors.

\section{Electrocoagulation combined with biological treatments}

The EC process consists on the use of iron or aluminum based-sacrificial anode material that will generate the coagulants responsible for the coagulation of colloidal matter [64-67]. It can remove the color, suspended solids and partial COD from wastewater [64,65]. EC processes have been proposed as pre-treatment [64] or polishing treatment [65] when combined with biological processes. The main most recent studies on this coupling have been described in Table 3. This combination has been implemented to treat industrial wastewaters such as landfill leachate [68], oil shale wastewater [69], dairy wastewater [70] and tannery wastewater

194 [71]. EC was mainly responsible in COD removal in the combined process, which allowed reaching the COD guidelines for effluent discharge $[64,65]$. However, the management of hydroxides' precipitates produced during EC need to be considered in the reactor design since the potentially toxic sludge can limit the efficiency of the bioprocess in an hybrid combination $[64,65]$. Moreover, most of the studies have been performed at lab-scale, which is not sufficient to assess the efficiency of combination. Still, one recent study presents a systematic comparison at lab-scale, pilot-scale and full-scale [69], demonstrating the ability to apply this combination at industrial scale. Further studies are required to optimize the scale up.

\section{Engineering approach and scale up}

204 If scale-up of conventional biological processes (activated sludge, biofilm reactors) is 205 relatively mature, scale-up of electrochemical reactors is still under development in this area 206 [72]. In the aim at optimizing the efficiency of the combined process, several engineering aspects need to be considered. An important factor concerns the design and sizing of the electrochemical and biological reactors. The choice of the electrochemical reactor configuration must depend on the effluent characteristics [73,74]. For low to moderate concentrated effluents with a low amount of particles, the mass transfer should be intensified

211 by implementing flow-through mode with porous electrode materials and/or thin-film reactors 
212 (e.g. micro-reactor [75-78], reactive electrochemical membrane (REM) [21], reactive electro-

213 mixing reactor [36]). For concentrated effluents, other configurations can be proposed such as

214 flow-by cells, reactive electro-mixing reactors [36] and flow electrochemical reactors [79].

215 For the pre or post biological treatment, most of the works have been focused on

216 biodegradability test and/or on batch activated sludge treatments [15]. Therefore, there is a

217 real need to better characterize and control the biological processes involved (transformation,

218 inhibition, etc.) in order to optimize the synergism between the two processes, especially by

219 defining the optimal operating conditions with real matrices. Only few studies are available

220 regarding the combined electrochemical/biological treatment at pilot-scale $[57,80]$ and full

221 scale [69]. However, these studies lack of dimensional analysis and scale-up approach for a

222 better optimization of the design and sizing. Moreover, further experiments need to be

223 performed under controlled operating conditions combined to kinetic models, residence time

224 distribution approach and computational fluid dynamics simulations. The use of statistical

225 analysis is lacking and need to be also done in order to address the reproducibility of the

226 results to ensure their robustness, especially when they are used for technico-economic study

227 and sizing estimation.

\section{Conclusions and future perspectives}

230 The efficiency of combination between electrochemical processes and biological treatment

231 has been demonstrated in literature, especially recently. The optimal electrochemical

232 conditions such as current density, electrode materials and retention time have been widely

233 investigated. This is important to note that the optimal conditions required in electrochemical

234 process alone are not typically the same than when the combination with a biological process

235 is considered. The biodegradability and therefore the kind of generated by-products need to be

236 also taken into account. There is a compromise to find between the high degradation and

237 mineralization yield to reach and the high biodegradability of effluent required for the

238 combination. Preliminary full-scale applications show promising opportunities of the coupling,

239 but chemical and electrochemical engineering approaches are the next crucial steps for its

240 viable application. 
243 [1] C.A. Martínez-Huitle, M.A. Rodrigo, I. Sirés, O. Scialdone, Single and coupled electrochemical processes and reactors for the abatement of organic water pollutants : A critical review, Chem. Rev. 115 (2015) 13362-13407. doi:10.1021/acs.chemrev.5b00361.

**Major detailed recent review on electrochemical advanced oxidation processes and the different ways to implement this process

249 [2] C.A. Martínez-huitle, M. Panizza, Electrochemical oxidation of organic pollutants for wastewater treatment, Curr. Opin. Electrochem. $11 \quad$ (2018) 62-72. doi:10.1016/j.coelec.2018.07.010.

**Major recent mini-review on electrochemical advanced oxidation processes for wastewqter

[3] B.P. Chaplin, The Prospect of Electrochemical Technologies Advancing Worldwide Water Treatment, Acc. Chem. Res. 52 (2019) 596-604. doi:10.1021/acs.accounts.8b00611.

[4] D. Seibert, C.F. Zorzo, F.H. Borba, R.M. de Souza, H.B. Quesada, R. Bergamasco, A.T. Baptista, J.J. Inticher, Occurrence, statutory guideline values and removal of contaminants of emerging concern by Electrochemical Advanced Oxidation Processes: A review, Sci. Total Environ. 748 (2020) 141527. doi:10.1016/j.scitotenv.2020.141527.

[6] M. Herraiz-Carboné, S. Cotillas, E. Lacasa, Á. Moratalla, P. Cañizares, M.A. Rodrigo, C. Sáez, Improving the biodegradability of hospital urines polluted with chloramphenicol by the application of electrochemical oxidation, Sci. Total Environ. 725 (2020) 138430. doi:10.1016/j.scitotenv.2020.138430.

268 [7] N. Prado, C. Montéléon, J. Ochoa, A. Amrane, Evaluation of the toxicity of veterinary antibiotics on activated sludge using modified Sturm tests - Application to tetracycline and tylosine antibiotics, J. Chem. Technol. Biotechnol. 85 (2010) 471-477. 
doi:10.1002/jctb.2312.

272

273

[8] M. Spérandio, E. Paul, Estimation of wastewater biodegradable COD fractions by combining respirometric experiments in various So/Xo ratios, Water Res. 34 (2000) $1233-1246$.

[9] H. Monteil, Y. Péchaud, N. Oturan, M.A. Oturan, A review on efficiency and cost effectiveness of electro- and bio-electro-Fenton processes: Application to the treatment of pharmaceutical pollutants in water, Chem. Eng. J. 376 (2019) 119577. doi:10.1016/j.cej.2018.07.179.

[10] J.P. Scott, D.F. Ollis, Integration of chemical and biological oxidation processes for water treatment: Review and recommendations, Environ. Prog. 14 (1995) 88-103. doi:10.1002/ep.670140212.

[11] Y.Y. Lou, F. Geneste, I. Soutrel, A. Amrane, F. Fourcade, Alachlor dechlorination prior to an electro-Fenton process: Influence on the biodegradability of the treated solution, Sep. Purif. Technol. 232 (2020) 115936. doi:10.1016/j.seppur.2019.115936.

**This work showed the influence of the electrolysis duration on the evolution of biodegradability and highlighted the roles of some functional groups of the molecule on its biorecalcitrance.

[12] S. Sanchis, A.M. Polo, M. Tobajas, J.J. Rodriguez, A.F. Mohedano, Degradation of chlorophenoxy herbicides by coupled Fenton and biological oxidation, Chemosphere. 93 (2013) 115-122. doi:10.1016/j.chemosphere.2013.04.097.

[13] H. Znad, H. Ohata, M.O. Tade, A net draft tube slurry airlift bioreactor for 2,4-D (2,4dichlorophenoxyacetic acid) pesticide biodegradation, Can. J. Chem. Eng. 88 (2010) 565-573. doi:10.1002/cjce.20306.

[14] F. Ferrag-Siagh, F. Fourcade, I. Soutrel, H. Aït-Amar, H. Djelal, A. Amrane, ElectroFenton pretreatment for the improvement of tylosin biodegradability., Environ. Sci. Pollut. Res. 21 (2014) 8534-8542. doi:10.1007/s11356-014-2771-5.

**This work highlighted the link between some physico-chemical parameters (COD, DOC, AOS) and biodegradability estimation .

[15] A. Aboudalle, H. Djelal, F. Fourcade, L. Domergue, A.A. Assadi, T. Lendormi, S. 
Taha, A. Amrane, Metronidazole removal by means of a combined system coupling an electro-Fenton process and a conventional biological treatment: By-products monitoring and performance enhancement, J. Hazard. Mater. 359 (2018) 85-95. doi:10.1016/j.jhazmat.2018.07.006.

[16] M. Panizza, G. Cerisola, Direct and mediated anodic oxidation of organic pollutants, Chem. Rev. 109 (2009) 6541-6569. doi:10.1021/cr9001319.

[17] N. Klidi, D. Clematis, M.P. Carpanese, A. Gadri, S. Ammar, M. Panizza, Electrochemical oxidation of crystal violet using a BDD anode with a solid polymer electrolyte, Sep. Purif. Technol. 208 (2019) $178-183$. doi:10.1016/j.seppur.2018.03.042.

[18] T.X.H. Le, H. Haflich, A.D. Shah, B.P. Chaplin, Energy-Efficient Electrochemical Oxidation of Perfluoroalkyl Substances Using a $\mathrm{Ti}_{4} \mathrm{O}_{7}$ Reactive Electrochemical Membrane Anode, Environ. Sci. Technol. Lett. 6 (2019) 504-510. doi:10.1021/acs.estlett.9b00397.

[19] C. Zhou, Y. Wang, J. Chen, J. Niu, Electrochemical degradation of sunscreen agent benzophenone-3 and its metabolite by $\mathrm{Ti} / \mathrm{SnO}_{2}-\mathrm{Sb} / \mathrm{Ce}-\mathrm{PbO}_{2}$ anode: Kinetics, mechanism, toxicity and energy consumption, Sci. Total Environ. 688 (2019) 75-82. doi:10.1016/j.scitotenv.2019.06.197.

[20] A. Kapałka, G. Fóti, C. Comninellis, The importance of electrode material in environmental electrochemistry Formation and reactivity of free hydroxyl radicals on boron-doped diamond electrodes, Electrochim. Acta. 54 (2009) 2018-2023. doi:10.1016/j.electacta.2008.06.045.

[21] C. Trellu, B.P. Chaplin, C. Coetsier, R. Esmilaire, S. Cerneaux, C. Causserand, M. Cretin, Electro-oxidation of organic pollutants by reactive electrochemical membranes, Chemosphere. 208 (2018) 159-175. doi:10.1016/j.chemosphere.2018.05.026.

**This review paper brings new perspectives on the use of reactive electrochemical membrane in electrooxidation of organic pollutants.

[22] J. Isidro, D. Brackemeyer, C. Sáez, J. Llanos, J. Lobato, P. Cañizares, T. Matthée, M.A. Rodrigo, Electro-disinfection with BDD-electrodes featuring PEM technology, Sep. Purif. Technol. 248 (2020) 117081. doi:10.1016/j.seppur.2020.117081. 
[23] J.A. Lara-Ramos, C. Saez, F. Machuca-Martínez, M.A. Rodrigo, Electro-ozonizers: A new approach for an old problem, Sep. Purif. Technol. 241 (2020). doi:10.1016/j.seppur.2020.116701.

[24] C. Trellu, O. Ganzenko, S. Papirio, Y. Pechaud, N. Oturan, D. Huguenot, E.D. van Hullebusch, G. Esposito, M.A. Oturan, Combination of anodic oxidation and biological treatment for the removal of phenanthrene and Tween 80 from soil washing solution, Chem. Eng. J. 306 (2016) 588-596. doi:10.1016/j.cej.2016.07.108.

[25] M.B. Carboneras, P. Cañizares, M.A. Rodrigo, J. Villaseñor, F.J. Fernandez-Morales, Improving biodegradability of soil washing effluents using anodic oxidation, Bioresour. Technol. 252 (2018) 1-6. doi:10.1016/j.biortech.2017.12.060.

**This paper evokes the interest of anodic oxidation with active anode combined with biological technology as more effective treatment compared to the use of non-active anode.

[26] A. Fernandes, P. Spranger, A. D. Fonseca, M.J. Pacheco, L. Ciríaco, A. Lopes, Effect of electrochemical treatments on the biodegradability of sanitary landfill leachates, Appl. Catal. B Environ. 144 (2014) 514-520. doi:10.1016/j.apcatb.2013.07.054.

[27] J.-M. Fontmorin, S. Huguet, F. Fourcade, F. Geneste, D. Floner, A. Amrane, Electrochemical oxidation of 2,4-Dichlorophenoxyacetic acid: Analysis of by-products and improvement of the biodegradability, Chem. Eng. J. 195-196 (2012) 208-217. doi:10.1016/j.cej.2012.04.058.

[28] H. Feng, Z. Chen, X. Wang, S. Chen, J. Crittenden, Electrochemical advanced oxidation for treating ultrafiltration effluent of a landfill leachate system: Impacts of organics and inorganics and economic evaluation, Chem. Eng. J. (2020) 127492. doi:10.1016/j.cej.2020.127492.

[29] J. De Coster, J. Liu, R. Van den Broeck, B. Rossi, R. Dewil, L. Appels, Influence of electrochemical advanced oxidation on the long-term operation of an Upflow Anaerobic Sludge Blanket (UASB) reactor treating 4-chlorophenol containing wastewater, Renew. Energy. 159 (2020) 683-692. doi:10.1016/j.renene.2020.04.037.

[30] M.B. Carboneras, J. Villaseñor, F.J. Fernández, M.A. Rodrigo, P. Cañizares, Selection of anodic material for the combined electrochemical-biological treatment of lindane 
polluted soil washing effluents, J. Hazard. Mater. $384 \quad$ (2020) 121237. doi:10.1016/j.jhazmat.2019.121237.

[31] J. Cai, M. Zhou, Y. Pan, X. Lu, Degradation of 2,4-dichlorophenoxyacetic acid by anodic oxidation and electro-Fenton using BDD anode: Influencing factors and $\begin{array}{llllll}\text { mechanism, } & \text { Sep. } & \text { Purif. } & \text { Technol. } & 230 & \text { (2020) }\end{array}$ doi:10.1016/j.seppur.2019.115867.

[32] M.E.H. Bergmann, J. Rollin, T. Iourtchouk, The occurrence of perchlorate during drinking water electrolysis using BDD anodes, Electrochim. Acta. 54 (2009) 21022107. doi:10.1016/j.electacta.2008.09.040.

[33] O. Azizi, D. Hubler, G. Schrader, J. Farrell, B.P. Chaplin, Mechanism of perchlorate formation on boron-doped diamond film anodes., Environ. Sci. Technol. 45 (2011) 10582-90. doi:10.1021/es202534w.

[34] M. El Kateb, C. Trellu, A. Darwich, M. Rivallin, M. Bechelany, S. Nagarajan, S. Lacour, N. Bellakhal, G. Lesage, M. Héran, M. Cretin, Electrochemical advanced oxidation processes using novel electrode materials for mineralization and biodegradability enhancement of nanofiltration concentrate of landfill leachates, Water Res. 162 (2019) 446-455. doi:10.1016/j.watres.2019.07.005.

[35] L. Guo, Y. Jing, B.P. Chaplin, Development and Characterization of Ultrafiltration $\mathrm{TiO}_{2}$ Magnéli Phase Reactive Electrochemical Membranes, Environ. Sci. Technol. 50 (2016) 1428-1436. doi:10.1021/acs.est.5b04366.

[36] E. Mousset, Unprecedented reactive electro-mixing reactor: Towards synergy between micro- and macro-reactors?, Electrochem. Commun. 118 (2020) 106787. doi:10.1016/j.elecom.2020.106787.

**This work introduces for the first time a possible combination between flow-through microreactor and macro-reactor for dealing with liquid and semi-liquid matrices at large scale, named as reactive electro-mixing reactor.

386 [37] E. Mousset, D.D. Dionysiou, Photoelectrochemical reactors for treatment of water and wastewater: a review, Environ. Chem. Lett. 18 (2020) 1301-1318. doi:10.1007/s10311-020-01014-9. 
[38] J.F. Pérez, J. Llanos, C. Sáez, C. López, P. Cañizares, M.A. Rodrigo, A microfluidic flow-through electrochemical reactor for wastewater treatment: A proof-of-concept, Electrochem. Commun. 82 (2017) 85-88. doi:10.1016/j.elecom.2017.07.026.

[39] A. Giwa, A. Dindi, J. Kujawa, Membrane bioreactors and electrochemical processes for treatment of wastewaters containing heavy metal ions, organics, micropollutants and dyes: Recent developments, J. Hazard. Mater. 370 (2019) 172-195. doi:10.1016/j.jhazmat.2018.06.025.

*This review paper summarizes the current challenges associated with the operation of standalone membrane bioreactors and electrochemical reactors including membrane fouling, set-backs from operational errors and conditions, energy consumption in electrochemical systems, high cost requirement, and the need for simplified models.

[40] B.M.B. Ensano, L. Borea, V. Naddeo, M.D.G. de Luna, V. Belgiorno, Control of emerging contaminants by the combination of electrochemical processes and membrane bioreactors, Environ. Sci. Pollut. Res. 26 (2019) 1103-1112.

[41] B.M.B. Ensano, L. Borea, V. Naddeo, V. Belgiorno, M.D.G. de Luna, F.C. Ballesteros, Combination of electrochemical processes with membrane bioreactors for wastewater treatment and fouling control: A review, Front. Environ. Sci. 4 (2016). doi:10.3389/fenvs.2016.00057.

[42] Z. Li, R. Dai, B. Yang, M. Chen, X. Wang, Z. Wang, An electrochemical membrane biofilm reactor for removing sulfonamides from wastewater and suppressing antibiotic resistance development: Performance and mechanisms, J. Hazard. Mater. 404 (2021) 124198. doi:10.1016/j.jhazmat.2020.124198.

[43] M. Zhou, M.A. Oturan, I. Sirés, Electro-fenton process : new trends and scale-up, in: Handb. Environ. Chem., Springer Singapore, 2018: p. 430.

[44] M. Arellano, N. Oturan, M. Pazos, M. Ángeles Sanromán, M.A. Oturan, Coupling electro-Fenton process to a biological treatment, a new methodology for the removal of ionic liquids?, Sep. $\quad$ Purif. $\quad$ Technol. $233 \quad$ (2020) 115990. doi:10.1016/j.seppur.2019.115990.

[45] N. Birjandi, H. Younesi, A.A. Ghoreyshi, M. Rahimnejad, Enhanced medicinal herbs wastewater treatment in continuous flow bio-electro-Fenton operations along with 
power generation, Renew. Energy. $155 \quad$ (2020) 1079-1090. doi:10.1016/j.renene.2020.04.013.

[46] H. Nadais, X. Li, N. Alves, C. Couras, H.R. Andersen, I. Angelidaki, Y. Zhang, Bioelectro-Fenton process for the degradation of Non-Steroidal Anti-Inflammatory Drugs in wastewater, Chem. Eng. J. 338 (2018) 401-410. doi:10.1016/J.CEJ.2018.01.014.

[47] J. Vidal, C. Huiliñir, R. Santander, J. Silva-Agredo, R.A. Torres-Palma, R. Salazar, Effective removal of the antibiotic Nafcillin from water by combining the photoelectroFenton process and anaerobic biological digestion, Sci. Total Environ. 624 (2018) 1095-1105. doi:10.1016/j.scitotenv.2017.12.159.

[48] M. Dehboudeh, P. Dehghan, A. Azari, M. Abbasi, Experimental investigation of petrochemical industrial wastewater treatment by a combination of integrated fixedfilm activated sludge (IFAS) and electro-Fenton methods, J. Environ. Chem. Eng. 8 (2020) 104537. doi:10.1016/j.jece.2020.104537.

[49] Y. Liu, K. Li, W. Xu, B. Du, Q. Wei, B. Liu, D. Wei, GO/PEDOT:NaPSS modified cathode as heterogeneous electro-Fenton pretreatment and subsequently aerobic granular sludge biological degradation for dye wastewater treatment, Sci. Total Environ. 700 (2020) 134536. doi:10.1016/j.scitotenv.2019.134536.

[50] S. Huo, D. Necas, F. Zhu, D. Chen, J. An, N. Zhou, W. Liu, L. Wang, Y. Cheng, Y. Liu, R. Ruan, Anaerobic digestion wastewater decolorization by $\mathrm{H}_{2} \mathrm{O}_{2}$-enhanced electro-Fenton coagulation following nutrients recovery via acid tolerant and proteinrich Chlorella production, Chem. Eng. J. $406 \quad$ (2021) 127160. doi:10.1016/j.cej.2020.127160.

[51] A.M. Gholizadeh, M. Zarei, M. Ebratkhahan, A. Hasanzadeh, F. Vafaei, Removal of Phenazopyridine from wastewater by merging biological and electrochemical methods via Azolla filiculoides and electro-Fenton process, J. Environ. Manage. 254 (2020) 109802. doi:10.1016/j.jenvman.2019.109802.

[52] A. Baiju, R. Gandhimathi, S.T. Ramesh, P. V. Nidheesh, Combined heterogeneous Electro-Fenton and biological process for the treatment of stabilized landfill leachate, J. Environ. Manage. 210 (2018) 328-337. doi:10.1016/j.jenvman.2018.01.019.

[53] D. Martínez-Pachón, M. Ibáñez, F. Hernández, R.A. Torres-Palma, A. Moncayo-Lasso, 
Photo-electro-Fenton process applied to the degradation of valsartan: Effect of parameters, identification of degradation routes and mineralization in combination with a biological system, J. Environ. Chem. Eng. $6 \quad$ (2018) 7302-7311. doi:10.1016/j.jece.2018.11.015.

453

454

455

[54] A.D. Webler, F.C. Moreira, M.W.C. Dezotti, C.F. Mahler, I.D.B. Segundo, R.A.R. Boaventura, V.J.P. Vilar, Development of an integrated treatment strategy for a leather tannery landfill leachate, Waste Manag. $89 \quad$ (2019) 114-128. doi:10.1016/j.wasman.2019.03.066.

[55] A. Popat, P.V. Nidheesh, T.S. Anantha Singh, M. Suresh Kumar, Mixed industrial wastewater treatment by combined electrochemical advanced oxidation and biological processes, Chemosphere. 237 (2019) 124419. doi:10.1016/j.chemosphere.2019.124419.

[56] W. Wang, Y. Lu, H. Luo, G. Liu, R. Zhang, S. Jin, A microbial electro-Fenton cell for removing carbamazepine in wastewater with electricity output, Water Res. 139 (2018) 58-65. doi:10.1016/j.watres.2018.03.066.

[57] R. Zou, I. Angelidaki, X. Yang, K. Tang, H.R. Andersen, Y. Zhang, Degradation of pharmaceuticals from wastewater in a 20-L continuous flow bio-electro-Fenton (BEF) system, Sci. Total Environ. 727 (2020) 138684. doi:10.1016/j.scitotenv.2020.138684.

[58] S. Li, Y. Liu, R. Ge, S. Yang, Y. Zhai, T. Hua, B.S. Ondon, Q. Zhou, F. Li, Microbial electro-Fenton: A promising system for antibiotics resistance genes degradation and energy generation, Sci. Total Environ. $699 \quad$ (2020) 134160. doi:10.1016/j.scitotenv.2019.134160.

[59] H. Olvera-Vargas, T. Cocerva, N. Oturan, D. Buisson, M.A. Oturan, BioelectroFenton: A sustainable integrated process for removal of organic pollutants from water: Application to mineralization of metoprolol, J. Hazard. Mater. 319 (2016) 13-23. doi:10.1016/j.jhazmat.2015.12.010.

**This work evaluates in detail the combination of electro-Fenton as pre-treatment followed by biological degradation. It makes emphasis in the operating parameters affecting electro-Fenton performance to increase the biodegradability, and the reaction mechanisms involved in the degradation of the model pollutant.

[60] E. Mousset, Z. Wang, H. Olvera-Vargas, O. Lefebvre, Advanced electrocatalytic pre- 
treatment to improve the biodegradability of real wastewater from the electronics industry - A detailed investigation study, J. Hazard. Mater. 360 (2018) 552-559. doi:10.1016/j.jhazmat.2018.08.023.

[61] M. Hassan, H. Olvera-Vargas, X. Zhu, B. Zhang, Y. He, Microbial electro-Fenton: An emerging and energy-efficient platform for environmental remediation, J. Power Sources. 424 (2019) 220-244. doi:10.1016/j.jpowsour.2019.03.112.

*This review paper presents a thorough account on the development of sustainable bioelectrochemical systems for wastewater treatment based on the Fenton's reaction: microbial-electro-Fenton.

[62] S.O. Ganiyu, C.A. Martínez-Huitle, The use of renewable energies driving electrochemical technologies for environmental applications, Curr. Opin. Electrochem. 22 (2020) 211-220. doi:10.1016/j.coelec.2020.07.007.

[63] S.O. Ganiyu, C.A. Martínez-Huitle, M.A. Rodrigo, Renewable energies driven electrochemical wastewater/soil decontamination technologies: A critical review of fundamental concepts and applications, Appl. Catal. B Environ. 270 (2020) 118857. doi:10.1016/j.apcatb.2020.118857.

[64] Z. Al-Qodah, Y. Al-Qudah, W. Omar, On the performance of electrocoagulationassisted biological treatment processes: a review on the state of the art, Environ. Sci. Pollut. Res. 26 (2019) 28689-28713. doi:10.1007/s11356-019-06053-6.

[65] Z. Al-Qodah, Y. Al-Qudah, E. Assirey, Combined biological wastewater treatment with electrocoagulation as a post-polishing process: A review, Sep. Sci. Technol. 55 (2020) 2334-2352. doi:10.1080/01496395.2019.1626891.

[66] J.N. Hakizimana, B. Gourich, M. Chafi, Y. Stiriba, C. Vial, P. Drogui, J. Naja, Electrocoagulation process in water treatment: A review of electrocoagulation modeling approaches, Desalination. 404 (2017) 1-21. doi:10.1016/j.desal.2016.10.011.

[67] S. Garcia-Segura, M.M.S.G. Eiband, J.V. de Melo, C.A. Martínez-Huitle, Electrocoagulation and advanced electrocoagulation processes: A general review about the fundamentals, emerging applications and its association with other technologies, J. Electroanal. Chem. 801 (2017) 267-299. doi:10.1016/j.jelechem.2017.07.047. 
[68] T.S. Le, N.M. Dang, D.T. Tran, Performance of coupling electrocoagulation and biofiltration processes for the treatment of leachate from the largest landfill in Hanoi, Vietnam: Impact of operating conditions, Sep. Purif. Technol. 255 (2021) 117677. doi:10.1016/j.seppur.2020.117677.

[69] L. Li, G. Qian, L. Ye, X. Hu, X. Yu, W. Lyu, Research on the enhancement of biological nitrogen removal at low temperatures from ammonium-rich wastewater by the bio-electrocoagulation technology in lab-scale systems, pilot-scale systems and a full-scale industrial wastewater treatment plant, Water Res. 140 (2018) 77-89. doi:10.1016/j.watres.2018.04.036.

**This article presents one of the primary work on a systematic comparison at lab-scale, pilot-scale and full-scale about the efficiency of combination between electrocoagulation and bioprocesses.

[70] J. Akansha, P. V. Nidheesh, A. Gopinath, K. V. Anupama, M. Suresh Kumar, Treatment of dairy industry wastewater by combined aerated electrocoagulation and $\begin{array}{lllll}\text { phytoremediation } & \text { process, } & \text { Chemosphere. } & 253 & \text { (2020) }\end{array}$ doi:10.1016/j.chemosphere.2020.126652.

[71] E.Ü. Deveci, C. Akarsu, Ç. Gönen, Y. Özay, Enhancing treatability of tannery wastewater by integrated process of electrocoagulation and fungal via using RSM in an economic perspective, Process Biochem. $84 \quad$ (2019) 124-133. doi:10.1016/j.procbio.2019.06.016.

[72] E. Lacasa, S. Cotillas, C. Saez, J. Lobato, P. Cañizares, M.A. Rodrigo, Environmental applications of electrochemical technology. What is needed to enable full-scale applications?, Curr. Opin. Electrochem. $16 \quad$ (2019) 149-156. doi:10.1016/j.coelec.2019.07.002.

[73] S. Garcia-Segura, A.B. Nienhauser, A.S. Fajardo, R. Bansal, C.L. Coonrod, J.D. Fortner, M. Marcos-Hernández, T. Rogers, D. Villagran, M.S. Wong, P. Westerhoff, Disparities between experimental and environmental conditions: Research steps toward making electrochemical water treatment a reality, Curr. Opin. Electrochem. 22 (2020) 9-16. doi:10.1016/j.coelec.2020.03.001.

[74] E. Mousset, K. Doudrick, A review of electrochemical reduction processes to treat 
oxidized contaminants in water, Curr. Opin. Electrochem. 22 (2020) 221-227. doi:10.1016/j.coelec.2020.07.008.

[75] J.F. Pérez, J. Llanos, C. Sáez, C. López, P. Cañizares, M.A. Rodrigo, Development of an innovative approach for low-impact wastewater treatment: A microfluidic flowthrough electrochemical reactor, Chem. Eng. J. 351 (2018) 766-772. doi:10.1016/j.cej.2018.06.150.

[76] P. Ma, H. Ma, S. Sabatino, A. Galia, O. Scialdone, Electrochemical treatment of real wastewater. Part 1: Effluents with low conductivity, Chem. Eng. J. 336 (2018) 133140. doi:10.1016/j.cej.2017.11.046.

[77] O. Scialdone, C. Guarisco, A. Galia, G. Filardo, G. Silvestri, C. Amatore, C. Sella, L. Thouin, Anodic abatement of organic pollutants in water in micro reactors, J. Electroanal. Chem. 638 (2010) 293-296. doi:10.1016/j.jelechem.2009.10.031.

[78] J.F. Pérez, J. Llanos, C. Sáez, C. López, P. Cañizares, M.A. Rodrigo, Towards the scale up of a pressurized-jet microfluidic flow-through reactor for cost-effective electrogeneration of $\mathrm{H}_{2} \mathrm{O}_{2}, \quad$ J. Clean. Prod. 211 (2019) 1259-1267. doi:10.1016/j.jclepro.2018.11.225.

[79] H. Monteil, Y. Pechaud, N. Oturan, C. Trellu, M.A. Oturan, Pilot scale continuous reactor for water treatment by electrochemical advanced oxidation processes: Development of a new hydrodynamic / reactive combined model, Chem. Eng. J. 404 (2020) 127048. doi:10.1016/j.cej.2020.127048.

**This paper presents the development of a new model that combine hydrodynamic and reaction in a novel continuous flow electrochemical pilot-scale reactor.

[80] R. Zou, I. Angelidaki, B. Jin, Y. Zhang, Feasibility and applicability of the scaling-up of bio-electro-Fenton system for textile wastewater treatment, Environ. Int. 134 (2020) 105352. doi:10.1016/j.envint.2019.105352. 
566

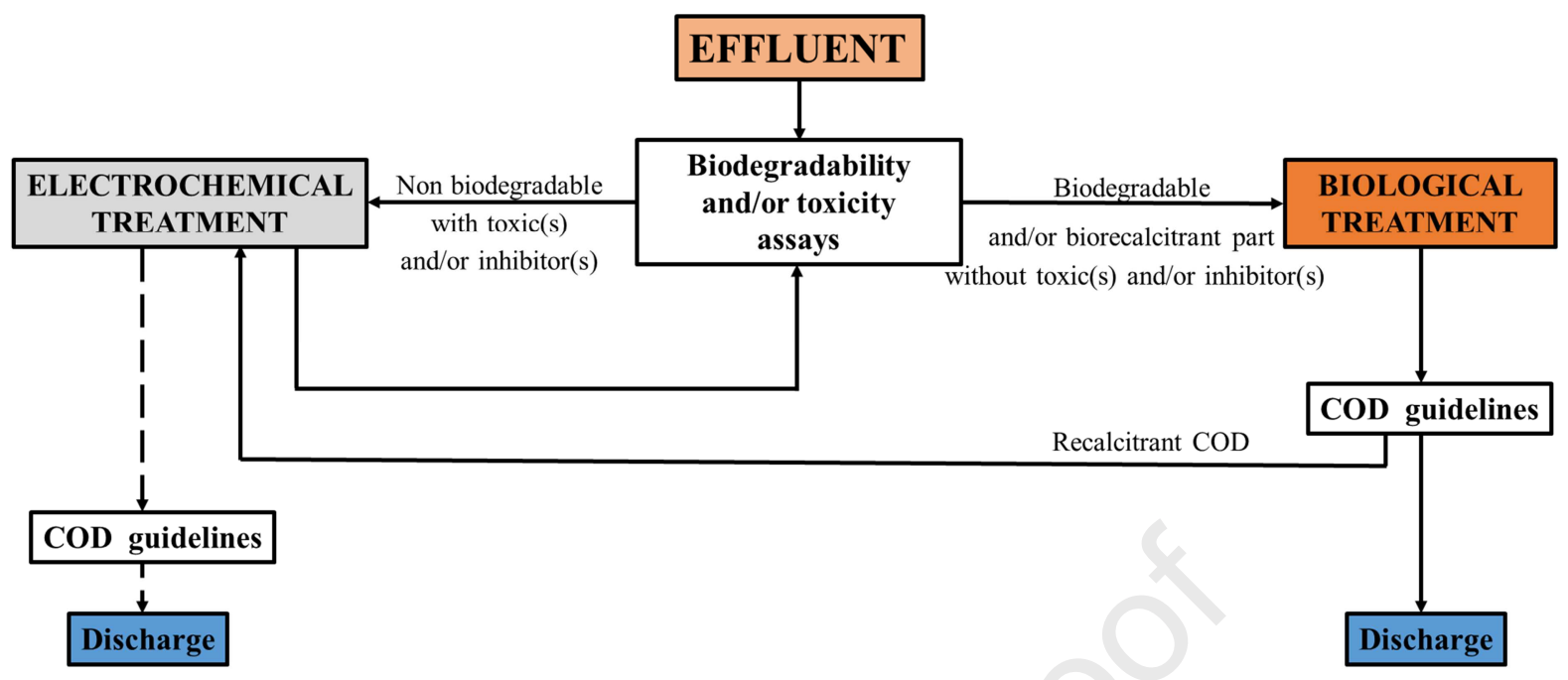

567

Figure 1. Combination strategy between electrochemical treatments and biological processes.

569

570

571 
Table 1. Summary of recent reports on the coupling between AO and a biological post-treatment.

\begin{tabular}{|c|c|c|c|c|c|c|}
\hline $\begin{array}{l}\text { Treatment system / } \\
\text { Wastewater }\end{array}$ & $\begin{array}{l}\text { Experimental setup } \\
\text { of AO / biological } \\
\text { treatment }\end{array}$ & $\begin{array}{l}\text { Operating } \\
\text { conditions } \\
\text { for AO }\end{array}$ & Removal efficiency & Biodegradability increase & $\begin{array}{l}\text { Energy } \\
\text { consumption }\end{array}$ & Ref. \\
\hline $\begin{array}{l}\text { AO with a biological } \\
\text { post-treatment } \\
\text { Synthetic soil washing } \\
\text { solution ( } 25 \mathrm{mg} \mathrm{L}^{-1} \text { of } \\
\text { phenanthrene and } 1.31 \mathrm{~g} \\
\mathrm{~L}^{-1} \text { of Tween } 80 ; 2.7 \mathrm{~g} \mathrm{~L}^{-} \\
1 \text { of COD) }\end{array}$ & $\begin{array}{l}\text { - Undivided, } \\
\text { cylindrical, open batch } \\
\text { reactor ( } 330 \mathrm{~mL}) \text {. } \\
\text { Anode: } \mathrm{Nb}-\mathrm{BDD} \\
\text { anode. Cathode: } \mathrm{SS} \\
\text { cathode. } \\
\text { - BOD tests and } \\
\text { operation of an } \\
\text { aerobic batch } \\
\text { biological reactor }\end{array}$ & $\begin{array}{l}{\left[\mathrm{Na}_{2} \mathrm{SO}_{4}\right]=} \\
50 \mathrm{mM} \\
\mathrm{j}=7-36 \mathrm{~mA} \\
\mathrm{~cm}^{-2}\end{array}$ & $\begin{array}{l}\text { AO alone: } 27 \% \text { COD } \\
\text { removal } \\
\text { Biological treatment } \\
\text { alone: } 44 \% \text { COD } \\
\text { removal } \\
\text { Combined process: } \\
80 \% \text { COD removal }\end{array}$ & $\begin{array}{l}\text { The ratio between the } \\
\text { ultimate BOD and the COD } \\
\text { increased from } 50 \% \\
\text { (untreated solution) to } 60- \\
95 \% \text { depending on } \\
\text { treatment time / current } \\
\text { intensity. }\end{array}$ & $\begin{array}{l}39 \mathrm{kWh}(\mathrm{kg} \\
\mathrm{COD})^{-1}\end{array}$ & [24] \\
\hline $\begin{array}{l}\text { AO with a biological } \\
\text { post-treatment. } \\
\text { Clopyralid-containing } \\
\text { soil washing effluent (no }\end{array}$ & $\begin{array}{l}\text { - Electrochemical flow } \\
\text { cell with a feed tank of } \\
5 \text { L. Anodes: Ir-MMO, } \\
\text { Ru-MMO, pSi-BDD } \\
\text { or carbon felt. }\end{array}$ & $\begin{array}{l}\text { Ions } \\
\text { mobilized } \\
\text { from the SW } \\
\text { step }\end{array}$ & $\begin{array}{l}\text { Ir-MMO and } \mathrm{Ru}- \\
\text { MMO: }<10 \% \\
\text { degradation and } \\
\text { mineralization } \\
\text { anodes: }<10 \%\end{array}$ & $\begin{array}{l}\text { Biodegradability was } \\
\text { assessed with CF at } 5 \mathrm{~mA} \\
\mathrm{~cm}^{-2} \text { (optimal conditions } \\
\text { for degradation of } \\
\text { clopyralid and }\end{array}$ & - & {$[25]$} \\
\hline
\end{tabular}




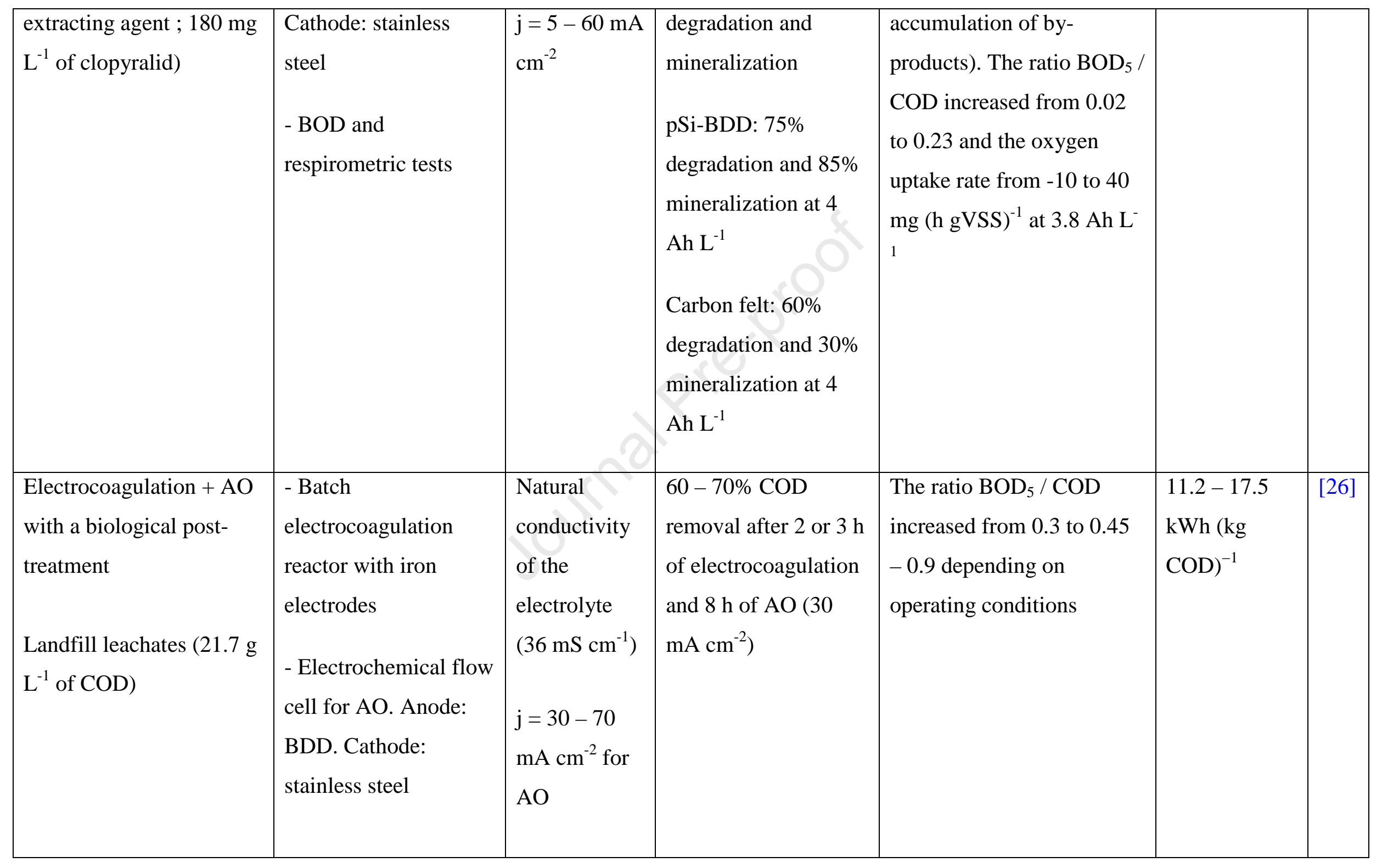




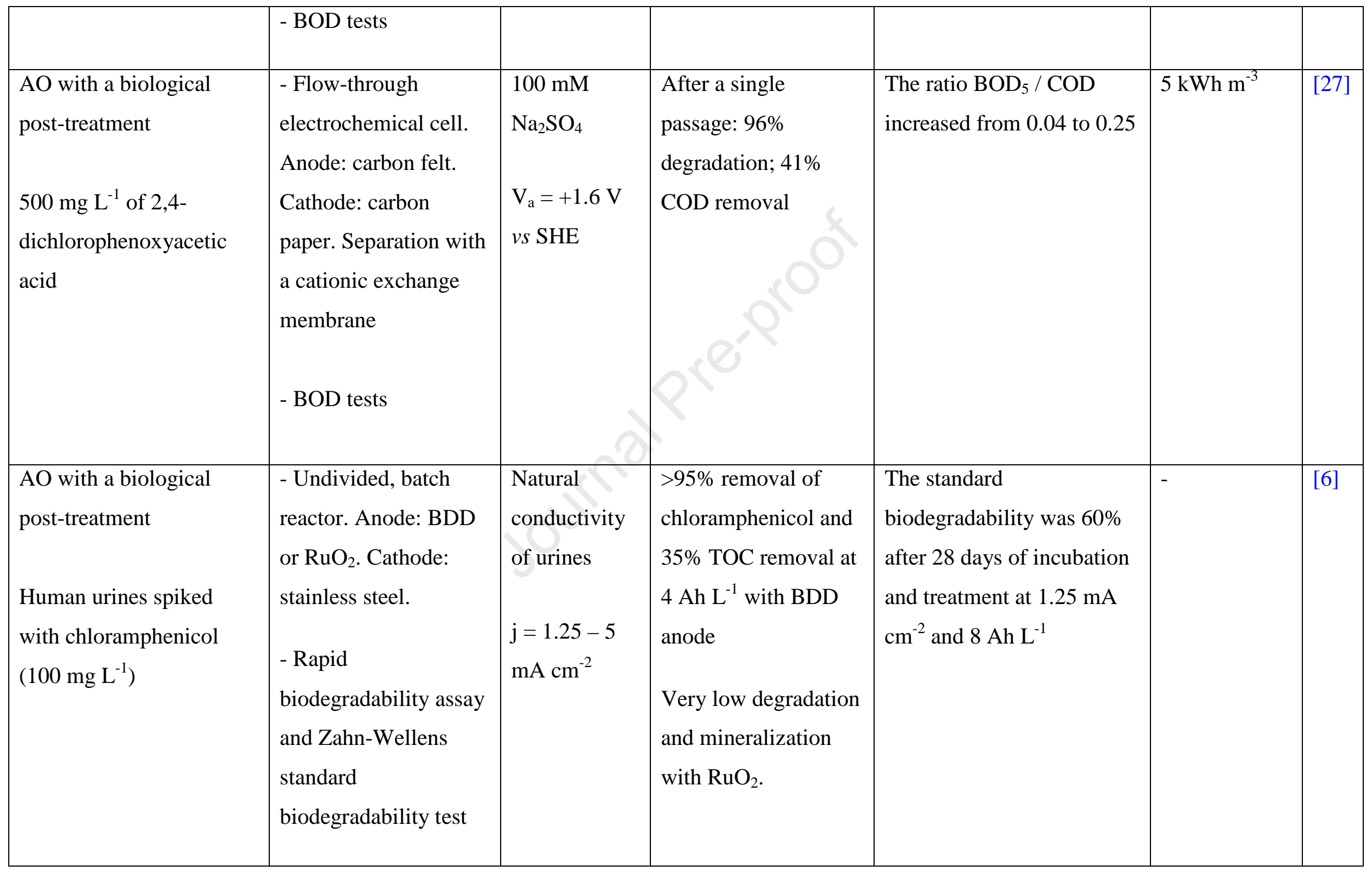


COD, chemical oxygen demand; BOD, biochemical oxygen demand; BDD, boron-doped diamond; MMO, mixed metal oxide; HPCD,

hydroxypropyl-beta-cyclodextrin; VSS, volatile suspended solids 
Table 2. Summary of recent reports on the coupling between EF and biological processes.

\begin{tabular}{|c|c|c|c|c|c|c|}
\hline $\begin{array}{l}\text { Treatment system / } \\
\text { wastewater }\end{array}$ & $\begin{array}{l}\text { Experimental setup } \\
\text { of EF / biological } \\
\text { treatment }\end{array}$ & Operating conditions & Removal efficiency & $\begin{array}{l}\text { Biodegradab } \\
\text { ility } \\
\text { increase }^{1}\end{array}$ & $\begin{array}{l}\text { Energy } \\
\text { consumption / } \\
\text { Power } \\
\text { generation }^{2}\end{array}$ & Ref. \\
\hline $\begin{array}{l}\text { Homogeneous EF + Bio } \\
\text { Ionic liquid 1-butyl-1- } \\
\text { methylpyrrolidinium } \\
\text { chloride ( } 1 \mathrm{mM}=177.7 \\
\left.\mathrm{mg} \mathrm{L}^{-1}\right), \mathrm{TOC}_{0}=108 \mathrm{mg} \\
\mathrm{L}^{-1}\end{array}$ & $\begin{array}{l}\text { EF: cylindrical } \\
\text { undivided cell }(230 \\
\mathrm{mL}) \text {, carbon felt } \\
\text { cathode }(19 \mathrm{~cm} \times 7 \\
\mathrm{cm} \times 0.5 \mathrm{~cm}) \text { and } \\
\text { BDD anode }\left(25 \mathrm{~cm}^{2}\right) \\
\text { Bio: bacteria } \\
\text { consortium } \\
\text { (Pseudonomas, } \\
\text { Bacillus, } \\
\text { Rhodococcus), lab } \\
\text { scale aerobic reactor } \\
\text { (flasks) }\end{array}$ & $\begin{array}{l}\text { EF: } I=1000 \mathrm{~mA}, \mathrm{pH}=3, \text { in } \\
0.05 \mathrm{M} \mathrm{Na}_{2} \mathrm{SO}_{4}, \mathrm{Fe}^{2+}=0.1 \\
\mathrm{mM} \text {, continuous air supply } \\
\text { Bio: mineral nutrients, } \mathrm{pH}= \\
7, \mathrm{~T}=30{ }^{\circ} \mathrm{C}\end{array}$ & $\begin{array}{l}\text { EF: } 57 \% \text { TOC } \\
\text { removal ( } 30 \text { min) } \\
\text { Bio: } 49 \% \text { TOC } \\
\text { removal (7 days) } \\
\text { Combined process: } \\
78 \% \text { TOC removal }\end{array}$ & $\begin{array}{l}\text { Increase of } \\
\text { the average } \\
\text { oxidation } \\
\text { state (AOS) } \\
\text { from } 0.48 \text { to } \\
1.43 \text { after EF }\end{array}$ & N/A & [44] \\
\hline Bio + homogeneous EF & Bio: plant $A$. & Bio: $200 \mathrm{~mL}$ nutrient & Bio: $85.9 \%$ removal & N/A & $28 \mathrm{kWh}(\mathrm{kg}$ & {$[51]$} \\
\hline
\end{tabular}




\begin{tabular}{|c|c|c|c|c|c|c|}
\hline $\begin{array}{l}\text { Phenazopyridine } \\
\text { (analgesic drug) }(20 \mathrm{mg} \\
\left.\mathrm{L}^{-1}\right)\end{array}$ & $\begin{array}{l}\text { filiculoides lab-scale } \\
\text { aerobic reactor } \\
\text { EF: undivided cell } \\
(250 \mathrm{~mL}) \text {, graphite } \\
\text { cathode and anode } \\
(1.2 \mathrm{~cm} \times 3.6 \mathrm{~cm} \times \\
0.3 \mathrm{~cm})\end{array}$ & $\begin{array}{l}\text { solution with air supply, } 20 \\
\mathrm{~g} \text { of plant, } \mathrm{pH}=7 \text {, } \\
\text { continuous air supply } \\
\mathrm{EF}: I=200 \mathrm{~mA}, \mathrm{pH}=3 \text {, in } \\
0.05 \mathrm{M} \mathrm{Na}_{2} \mathrm{SO}_{4}, 0.3 \mathrm{~g} \text { of } \\
\mathrm{Fe}_{2} \mathrm{SO}_{4}\end{array}$ & $\begin{array}{l}\text { of the drug and } 57.6 \% \\
\text { TOC removal (at } 48 \\
\text { h) } \\
\text { EF: } 22.25 \% \text { TOC } \\
\text { removal ( } 12 \mathrm{~h}) \\
\text { Combined process: } \\
79.9 \% \text { TOC removal } \\
(60 \mathrm{~h})\end{array}$ & & $\mathrm{TOC}^{-1}$ & \\
\hline $\begin{array}{l}\text { Heterogeneous } \mathrm{EF}+\mathrm{Bio} \\
\text { Stabilized landfill } \\
\text { leachate } \\
\left(\mathrm{COD}=7184 \mathrm{mg} \mathrm{L}^{-1} \text {, }\right. \\
\left.\mathrm{BOD}_{5} / \mathrm{COD}=0.03\right)\end{array}$ & $\begin{array}{l}\text { EF: undivided cell } \\
(750 \mathrm{~mL}), \mathrm{Ti} / \mathrm{TiO}_{2} \\
\text { anode }(8 \mathrm{~cm} \times 7 \mathrm{~cm} \\
\times 0.4 \mathrm{~cm}), \text { graphite } \\
\text { cathode }(8 \mathrm{~cm} \times 7 \\
\mathrm{cm} \times 0.5 \mathrm{~cm}) \\
\text { Bio: soil bacteria, } \\
100 \mathrm{~mL} \text { aerobic } \\
\text { reactor }\end{array}$ & $\begin{array}{l}\mathrm{EF}: E_{\text {cell }}=5 \mathrm{~V}, \mathrm{pH}=3,50 \\
\mathrm{mg} \mathrm{L}{ }^{-1} \mathrm{FeMoPO} \\
\text { nanoparticles, constant air } \\
\text { supply } \\
\text { Bio: } 100 \mathrm{~mL} \text { nutrient } \\
\text { solution with } 1 \mathrm{~mL} \text { of } \\
\text { isolated colonies, } \mathrm{pH}=8, \mathrm{~T} \\
=37^{\circ} \mathrm{C}\end{array}$ & $\begin{array}{l}\text { EF: } 82 \% \text { COD } \\
\text { removal }(1.5 \mathrm{~h}) \\
\text { Bio: } 15 \% \text { COD } \\
\text { removal (5 days) } \\
\text { Combined process: } \\
97 \% \text { COD removal }\end{array}$ & $\begin{array}{l}\mathrm{BOD}_{5} / \mathrm{COD} \\
\text { increase from } \\
0.03 \text { to } 0.4 \text { by } \\
\mathrm{EF}(1.5 \mathrm{~h})\end{array}$ & N/A & [52] \\
\hline
\end{tabular}




\begin{tabular}{|c|c|c|c|c|c|c|}
\hline $\begin{array}{l}\text { SPEF + Bio } \\
\text { Valsartan } \\
\text { (antihypertensive drug) } \\
\left(20 \mathrm{mg} \mathrm{L}^{-1}\right)\end{array}$ & $\begin{array}{l}\text { SPEF: undivided cell } \\
(200 \mathrm{~mL}), \mathrm{Ti} / \mathrm{IrO}_{2}- \\
\mathrm{SnO}_{2} \text { anode ( } 2.89 \\
\left.\mathrm{~cm}^{2}\right) \text {, carbon felt air } \\
\text { diffusion cathode ( } 2 \\
\left.\mathrm{~cm}^{2}\right), \mathrm{UV} \text { lamp with } \\
\square=368 \mathrm{~nm} \\
\text { Bio: aerobic reactor } \\
(900 \mathrm{~mL}) \text { with } \\
\text { aerobic sludge from } \\
\text { a food processing } \\
\text { plant }\end{array}$ & $\begin{array}{l}\text { SPEF: } j=3.46 \mathrm{~mA} \mathrm{~cm}^{-2}, \text { in } \\
0.05 \mathrm{M} \mathrm{NaCl}, \mathrm{Fe}^{2+}=0.036 \\
\mathrm{mM}, \mathrm{pH}=3 \\
\text { Bio: } 4000 \mathrm{mg} \mathrm{L}^{-1} \text { of } \\
\text { biomass, } \mathrm{pH}=7, \mathrm{~T}=37^{\circ} \mathrm{C}\end{array}$ & $\begin{array}{l}\text { SPEF: total } \\
\text { degradation }(45 \mathrm{~min}) \\
\text { and }>20 \% \text { TOC } \\
\text { removal }(90 \mathrm{~min}) \\
\text { Bio: } 80 \% \text { TOC } \\
\text { removal ( } 8 \text { days) }\end{array}$ & N/A & N/A & [53] \\
\hline
\end{tabular}




\begin{tabular}{|c|c|c|c|c|c|c|}
\hline & $\begin{array}{l}\text { from a municipal } \\
\text { wastewater plant }\end{array}$ & & & & & \\
\hline $\begin{array}{l}\text { Bio + Coagulation + PEF } \\
+ \text { Bio } \\
\text { Leather tannery landfill } \\
\text { leachate } \\
\left(\mathrm{COD}=13966 \mathrm{mg} \mathrm{L}^{-1},\right. \\
\text { alkalinity }=28,800 \mathrm{mg} \mathrm{L}^{-} \\
{ }^{1}, \mathrm{BOD}_{5} / \mathrm{COD}^{-}=0.31, \\
\mathrm{NH}_{4}^{+}=8403 \mathrm{mg} \mathrm{L}{ }^{-1}, \mathrm{TN} \\
=10390 \mathrm{mg} \mathrm{L}^{-1}, \mathrm{TSS}^{-} \\
\left.1187 \mathrm{mg} \mathrm{L}^{-1}, \mathrm{pH}=8.6\right)\end{array}$ & $\begin{array}{l}\text { Bio: Continuous } \\
\text { flow anoxic/aerobic } \\
\text { reactor (9 L-anoxic } \\
\text { tank, } 7 \text { L-aerobic } \\
\text { tank, } 3.2 \text { L-clarifier) } \\
\text { Coagulation: } 10 \text { L } \\
\text { coagulation tank } \\
\text { PEF: filter-press } \\
\text { recirculation reactor } \\
(2.5 \text { L), carbon- } \\
\text { PTFE cathode (10 } \\
\text { cm²), BDD anode } \\
\left(10 \mathrm{~cm}^{2}\right), \text { tubular } \\
\text { photoreactor with } \\
\text { UVA lamp } \\
\text { Bio: Zhan-Wellens }\end{array}$ & $\begin{array}{l}\text { Bio: Nitrification- } \\
\text { denitrification, flow rate }= \\
0.3 \mathrm{~L} \mathrm{day}^{-1}, 1.2 \mathrm{~L} \mathrm{day}^{-1} \\
\text { returning activated sludge, } \\
1 \mathrm{~h} \text { sedimentation, sludge } \\
\text { removal } \\
\text { Coagulation: } \mathrm{pH}=3, \mathrm{Fe}= \\
400 \mathrm{mg} \mathrm{L}^{-1}\left(\mathrm{FeCl}_{3}\right), 3 \mathrm{~h} \\
\text { sedimentation } \\
\text { SPEF: } j=300 \mathrm{~mA} \mathrm{~cm}^{-2} \mathrm{Fe}= \\
150 \mathrm{mg} \mathrm{L}^{-1}, \mathrm{pH}=2.8, \text { flow } \\
\text { rate }=55 \mathrm{~L} \mathrm{~h}^{-1}, \\
\text { neutralization, } 3 \mathrm{~h} \\
\text { sedimentation } \\
\text { Bio: } 28 \text { days } \mathrm{Zhan}-\mathrm{Wellens} \\
\text { test, } 1 \mathrm{~h} \text { sedimentation, }\end{array}$ & $\begin{array}{l}\text { Bio: } 97 \% \text { alkalinity } \\
\text { removal, 40\% COD } \\
\text { removal, >99\% } \mathrm{NH}_{4}^{+} \\
\text {removal, 95\% TN } \\
\text { removal } \\
\text { Coagulation: 49\% } \\
\text { TSS removal, 66.3\% } \\
\text { COD removal, 50\% } \\
\text { TN removal (30 min) } \\
\text { SPEF: 96.4\% COD } \\
\text { removal, 95\% TSS } \\
\text { removal, 38.5 TN } \\
\text { removal (9.3 h) } \\
\text { Bio: 45\% COD } \\
\text { removal, 18.8\% TN } \\
\text { removal }\end{array}$ & $\begin{array}{l}\mathrm{BOD}_{5} / \mathrm{COD} \\
\text { increase from } \\
0.003 \text { to } 0.2 \\
\text { by PEF }\end{array}$ & $\begin{array}{l}469 \mathrm{kWh} \mathrm{m}^{-3} \\
(\mathrm{PEF}) \\
20 \mathrm{MJ} \mathrm{m}^{-3} \\
\text { (UVA lamp } \\
\text { operation) }\end{array}$ & [54] \\
\hline
\end{tabular}




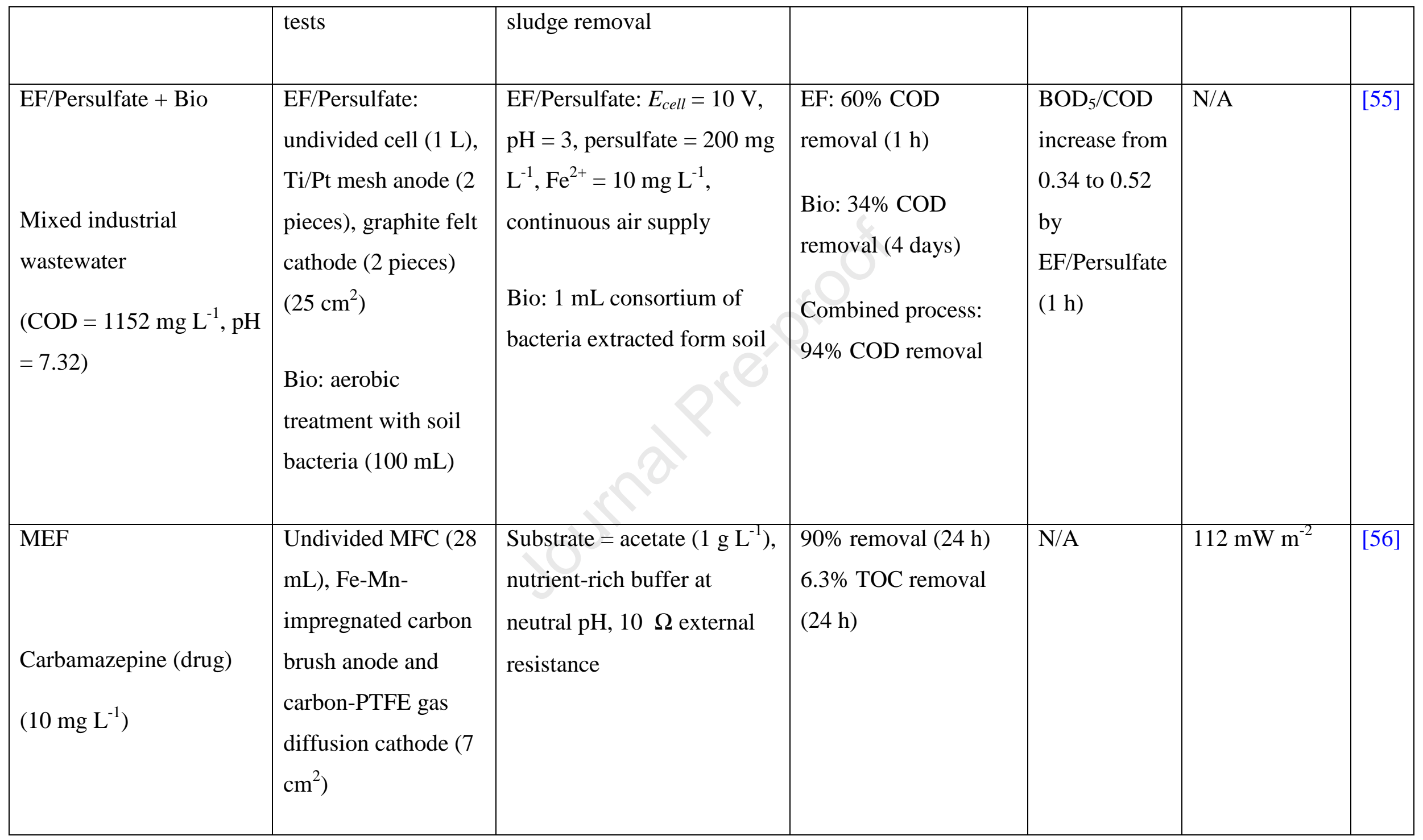




\begin{tabular}{|c|c|c|c|c|c|c|}
\hline $\begin{array}{l}\text { MEF } \\
\text { Pharmaceutical mixture } \\
\text { in municipal wastewater } \\
\text { matrix (clofibric acid, } \\
\text { diclofenac, } \\
\text { carbamazepine, } \\
\text { naproxen, ibuprofen, } \\
\text { ketoprofen) } \\
\left(0.5 \text { mg L }{ }^{-1} \text { each) }\right.\end{array}$ & $\begin{array}{l}\text { 20-L MFC with } \\
\text { CEM, } 20 \text { carbon } \\
\text { brush anodes ( } 5.9 \\
\text { cm diameter } \times 6.9 \\
\mathrm{~cm}), 20 \text { graphite } \\
\text { plate cathodes }(4.5 \\
\mathrm{cm} \times 4.5 \mathrm{~cm})\end{array}$ & $\begin{array}{l}\text { Cathode chamber }(9 \mathrm{~L}): E= \\
0.2 \mathrm{~V} \text { vs } \mathrm{SCE} \text {, in } 0.05 \mathrm{M} \\
\mathrm{Na}_{2} \mathrm{SO}_{4}, \mathrm{pH}=2.8, \mathrm{Fe}^{2+} \\
\text { catalyst, } 0.1 \Omega \text { external } \\
\text { resistance, constant air } \\
\text { supply. } \\
\text { Anode chamber: domestic } \\
\text { wastewater with } 1 \mathrm{~g} \mathrm{~L}^{-1} \\
\text { acetate in nutrient medium }\end{array}$ & $\begin{array}{l}58 \%, 87 \%, 76 \%, 96 \%, \\
92 \%, \text { and } 86 \% \\
\text { degradation of } \\
\text { clofibric acid, } \\
\text { diclofenac, } \\
\text { carbamazepine, } \\
\text { naproxen, ibuprofen, } \\
\text { ketoprofen, } \\
\text { respectively }(26 \mathrm{~h})\end{array}$ & $5.84 € \mathrm{~m}^{-3}$ & N/A & [57] \\
\hline
\end{tabular}




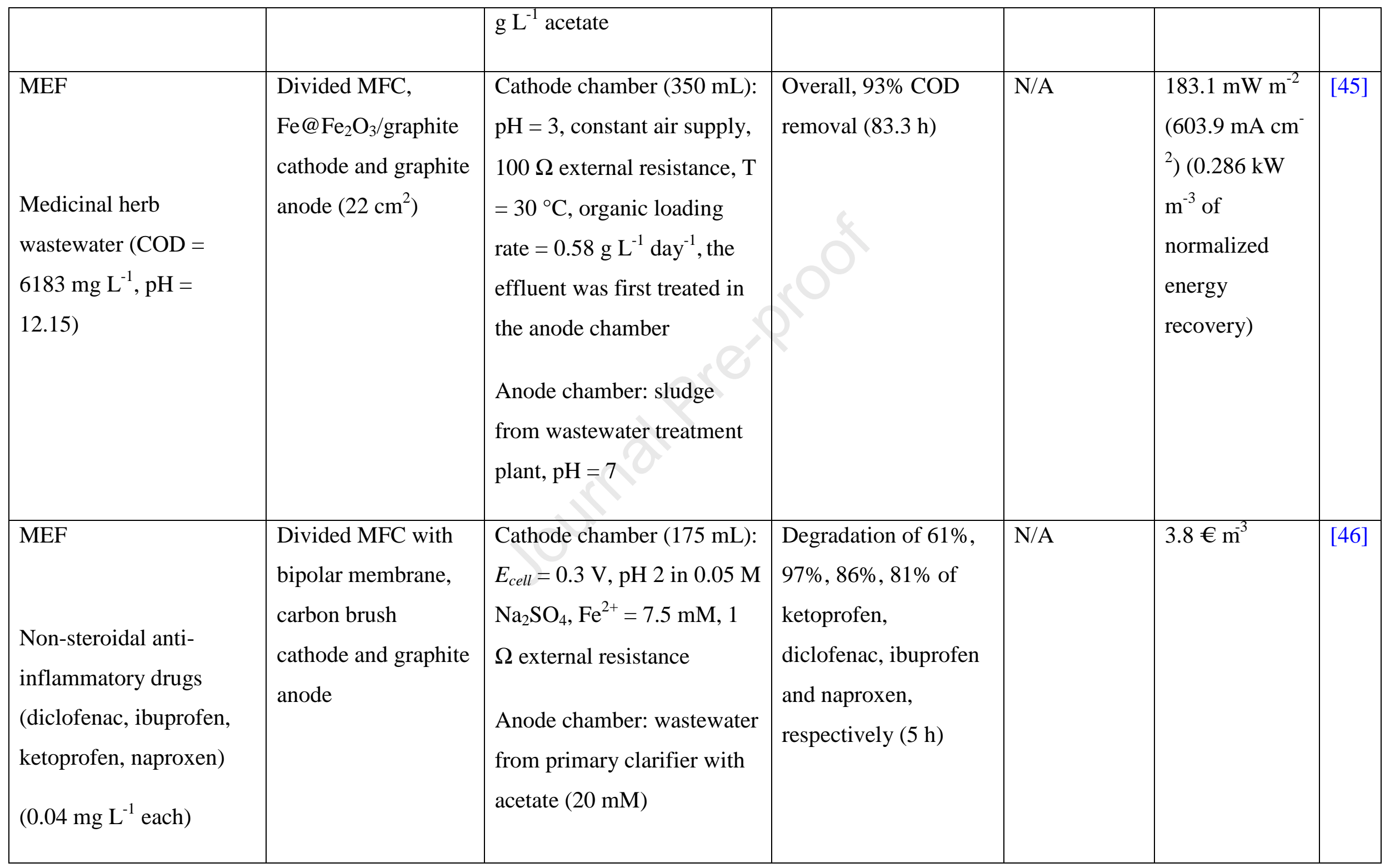


${ }^{1}$ Does not apply for MEF systems.

${ }^{2}$ Power generation only in the case of MEF.

CEM, cation exchange membrane; CNT, carbon nanotubes; FeMoP, iron molybdenum phosphate; PTFE, polytetrafluoroethylene; PEF, photoelectro-Fenton; SPEF, solar photoelectro-Fenton; SS, stainless steel; TN, total nitrogen; TSS, total suspended solids. 
Table 3. Summary of recent reports on the coupling between EC and biological processes.

\begin{tabular}{|c|c|c|c|c|c|c|}
\hline $\begin{array}{l}\text { Treatment system / } \\
\text { wastewater }\end{array}$ & $\begin{array}{l}\text { Experimental setup of EC } \\
\text { / biological treatment }\end{array}$ & $\begin{array}{l}\text { Operating } \\
\text { conditions }\end{array}$ & $\begin{array}{l}\text { Removal } \\
\text { efficiency }\end{array}$ & $\begin{array}{l}\text { Biodegradability } \\
\text { increase }\end{array}$ & $\begin{array}{l}\text { Energy } \\
\text { consumption }\end{array}$ & Ref. \\
\hline $\begin{array}{l}\text { EC-biological in hybrid } \\
\text { system } \\
\text { Lab-scale: synthetic } \\
\text { wastewater (COD }=600 \\
\mathrm{mg} \mathrm{L}^{-1}, \mathrm{NH}_{4}^{+}=200 \mathrm{mg}\end{array}$ & $\begin{array}{l}\text { Lab-scale: four sequencing } \\
\text { batch reactor (SBRs) ( } 8 \mathrm{~L} \\
\text { each) including } 2 \mathrm{SBRS} \\
\text { with Fe anode and carbon } \\
\text { cathode ( } 150 \times 60 \times 5 \mathrm{~mm} \\
\text { each) }\end{array}$ & $\begin{array}{l}\text { Lab-scale: (EC: } 0.01 \\
\text { A, electrodes gap = } \\
6-8 \mathrm{~cm} \text {; bio: HRT = } \\
16 \mathrm{~h} \text { at different } \\
\text { temperature) }\end{array}$ & $\begin{array}{l}\text { Lab-scale: } \\
\text { combined } \\
\text { process }=92 \% \\
\text { COD and } 55 \% \\
\text { nitrate }\end{array}$ & - & - & [69] \\
\hline
\end{tabular}




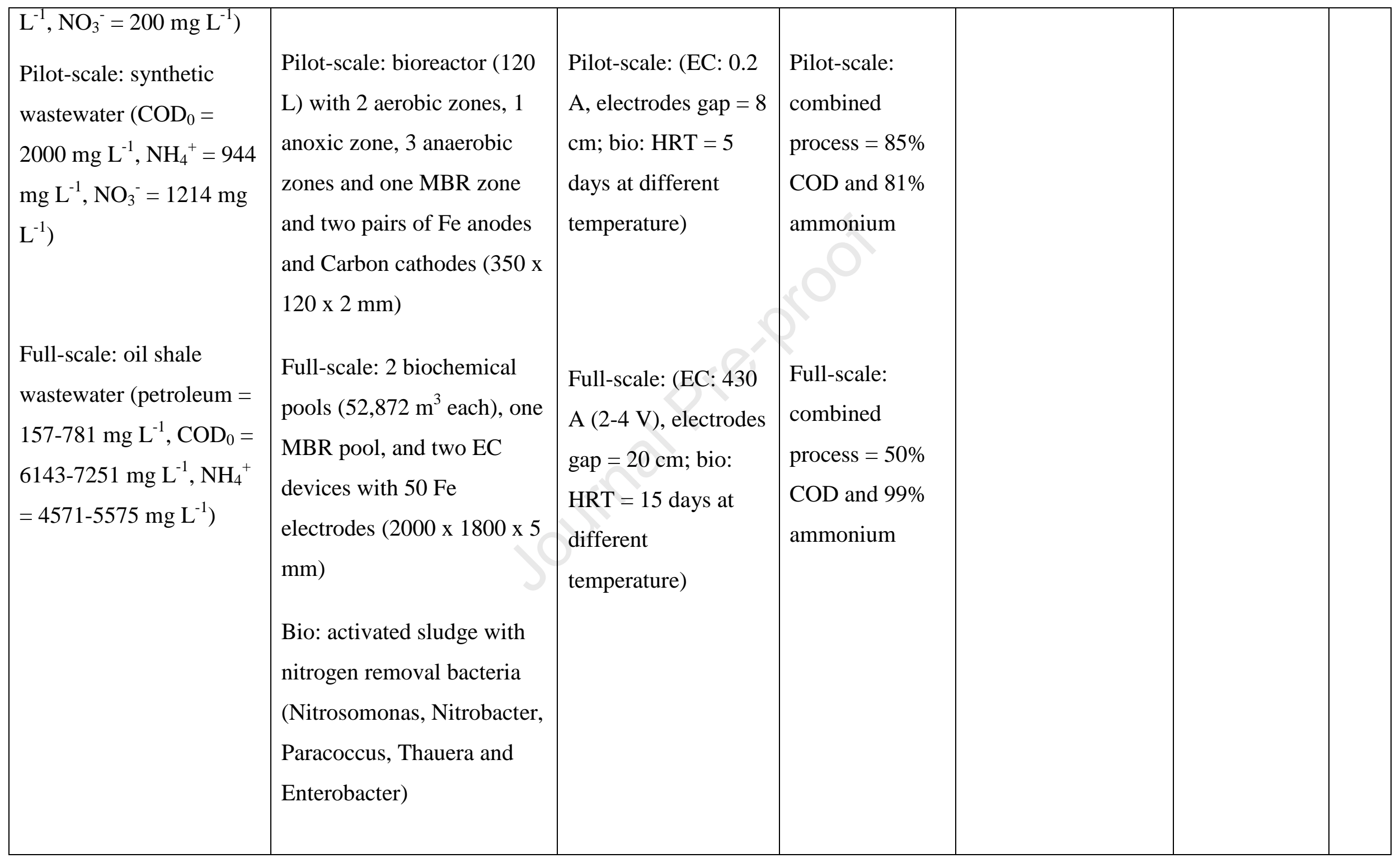




\begin{tabular}{|c|c|c|c|c|c|c|}
\hline $\begin{array}{l}\mathrm{EC}+\text { phytoremediation } \\
\text { as post-treatment } \\
\text { Dairy industry } \\
\text { wastewater: } \mathrm{COD}_{0}= \\
5600 \mathrm{mg} \mathrm{L}^{-1}, \mathrm{NO}_{3}{ }^{-}=616 \\
\mathrm{mg} \mathrm{L}^{-1}\end{array}$ & $\begin{array}{l}\text { EC: parallelepiped } \\
\text { undivided reactor }(1 \mathrm{~L}) \text {, } \\
\text { iron }(50 \mathrm{~mm} \times 100 \mathrm{~mm} \times 3 \\
\mathrm{mm}) \text { or aluminum anode } \\
(50 \mathrm{~mm} \times 100 \mathrm{~mm} \times 2 \\
\mathrm{mm}) \text {, electrodes gap }=10 \\
\mathrm{~mm} \\
\text { Bio: Canna indica plant }\end{array}$ & $\begin{array}{l}\text { EC: } 2.5-5 \mathrm{~V} \text {, } \\
\text { continuous air } \\
\text { supply } \\
\text { Bio: plant growth } \\
\text { during six weeks } \\
\text { with nutrients } \\
\text { coming from the } \\
\text { wastewater itself (not } \\
\text { the soil) }\end{array}$ & $\begin{array}{l}\text { EC: } 86 \% \text { COD } \\
\text { and } 76 \% \text { nitrate } \\
(120 \mathrm{~min}) \\
\text { Combined } \\
\text { process: } 98 \% \\
\text { COD and } 84 \% \\
\text { nitrate }\end{array}$ & $\begin{array}{l}\text { No increase of } \\
\text { biodegradability } \\
\text { after EC and after } \\
\text { phytoremediation }\end{array}$ & - & \begin{tabular}{|l}
$70]$ \\
\end{tabular} \\
\hline $\begin{array}{l}\text { EC + biological fungal } \\
\text { post-treatment } \\
\text { Tannery wastewater: } \\
\mathrm{COD}_{0}=18800 \mathrm{mg} \mathrm{L}^{-1} \text {, } \\
\mathrm{Cr}^{6+}=22.3 \mathrm{mg} \mathrm{L}^{-1}\end{array}$ & $\begin{array}{l}\text { EC: parallelepiped } \\
\text { undivided reactor }(0.8 \mathrm{~L}) \text {, } \\
\text { iron cathode and aluminum } \\
\text { anode }(60 \mathrm{~mm} \times 85 \mathrm{~mm} \times 1 \\
\mathrm{mm}) \text {, electrodes gap }=20 \\
\mathrm{~mm} \\
\text { Bio: Aspergillus niger fungi }\end{array}$ & $\begin{array}{l}\text { EC: } \mathrm{pH} 8,0.18 \mathrm{~A} \\
\text { Bio: } \mathrm{pH} 5,2 \% \\
\text { inoculum rate, } 36 \mathrm{~h}\end{array}$ & $\begin{array}{l}\text { EC: } 64 \% \mathrm{COD} \\
\text { and } 90 \% \mathrm{Cr}^{6+} \\
(60 \mathrm{~min}) \\
\text { Combined } \\
\text { process: } 96 \% \\
\text { COD and } 97 \% \\
\mathrm{Cr}^{6+}\end{array}$ & - & $1.73 \$ \mathrm{~m}^{-3}$ & {$[71]$} \\
\hline
\end{tabular}

HRT, hydraulic retention time 